medRxiv preprint doi: https://doi.org/10.1101/2020.04.16.20067355; this version posted April 17, 2020. The copyright holder for this preprint (which was not certified by peer review) is the author/funder, who has granted medRxiv a license to display the preprint in perpetuity. It is made available under a CC-BY-NC-ND 4.0 International license.

\title{
Do Weather Temperature and Median-age affect COVID-19 Transmission?
}

\author{
Aly Zein Elabdeen Kassem, Ph.d ${ }^{1}$ \\ Institute of National Planning, Egypt
}

\begin{abstract}
It was observed that the coldest countries and the eldest in terms of medianage were most distressed by COVID-19 pandemic, while the warmest countries and that have younger-aged population were the least affected. Therefore, this study utilized the non-linear least squares method to estimate the impact of weather temperatures and median age on COVID19 cases per million in thirty-nine countries divided into two groups. The first group composed of twenty-four countries that announced the first COVID-19 case in January 2020, while the second group contains fifteen countries that witnessed the pandemic for the first time in February of the same year. The study revealed some major findings, which are: COVID19 cases per million were not significantly affected by weather temperature or the median age in "January-group" countries (after 72.67 days on average), while COVID-19 cases per million increased significantly by decreasing temperatures, and increasing the median age in case of "February-group" countries (after an average of 44.80 days). This means that weather temperature and median age may influence the transmission rates of COVID-19 in its early stages, while weather temperature or median age no longer have effects in the advanced stages of the pandemic.
\end{abstract}

Keywords: COVID-19, SARS-CoV-2, Weather Temperature, Median Age

\section{Introduction}

There is no doubt that the containment of COVID-19 pandemic caused by the emerging coronavirus (SARS-CoV-2) is currently the first concern worldwide. Since the characteristics of this pandemic that started in Wuhan, China in late 2019, made it difficult even by the most advanced health systems to control over it. This pandemic, which has spread to most countries of the world due its extremely high transmission rate of 2-2.5 (WHO, 2020-1), not only more targets the elder age categories, but it may 
medRxiv preprint doi: https://doi.org/10.1101/2020.04.16.20067355; this version posted April 17, 2020. The copyright holder for this preprint (which was not certified by peer review) is the author/funder, who has granted medRxiv a license to display the preprint in perpetuity. It is made available under a CC-BY-NC-ND 4.0 International license .

also target specific places in the world, but rather specific areas in the country itself.

The number of COVID-19 cases globally as of April 10, 2020, at 14:27 GMT, was 1,625,213 cases, of which, $22 \%$ recovered, $5.95 \%$ died, and $71.47 \%$ were still active. According to official statistics, China, the source of the pandemic, managed to close $94.56 \%$ of cases with recovery, $4.07 \%$ with deaths (two cases per one million), and only $1.36 \%$ of cases were still active. While the USA topped the most affected countries' list, with a number of cases amounted to 470,175 , represented $28.93 \%$ of global cases, of which $90.9 \%$ cases were still active. Furthermore, the combined COVID-19 cases in Spain, Italy, Germany and France accounted for $33.09 \%$ of global cases as of study time (WORLDMETERS, 2020).

This paper investigates the impact of weather temperatures and median age individually on the number of COVID-19 cases per million.

\section{Literature}

\subsection{Effect of temperature on COVID-19 transmission}

A number of studies (Wang, Tang, Feng, \& Lv, April 3, 2020; Sajadi \& et. al., 2020; Chan, Peiris, Poon, \& Seto, 2011; Casanova, Jeon, Rutala, Weber, \& Sobsy, 2010; Altamimi \& Ahmd, 2019) have proven that temperature and high relative humidity reduce the transmission rate of coronaviruses.

(Gundy \& Gebra, 2009) have demonstrated that the activity of SARS virus in water is highly dependent on temperature, as the virus is rapidly inactivated in water at a temperature of $23^{\circ} \mathrm{C}$ for ten days compared to more than 100 days at a temperature of $4^{\circ} \mathrm{C}$. In 2010 (Casanova, Jeon, Rutala, Weber, \& Sobsy, 2010) recorded that SARS Cov was inactivated faster at $20^{\circ} \mathrm{C}$ compared to $4^{\circ} \mathrm{C}$ at all levels of relative humidity (above $20 \%$ ), and that virus was inactivated faster at $40^{\circ} \mathrm{C}$ than $20^{\circ} \mathrm{C}$. (Chan, Peiris, Poon, \& Seto, 2011) explained in 2011 that SARS Cov virus retain its vitality for more than five days on surfaces at a temperature of $22-25^{\circ} \mathrm{C}$ and relative humidity between $40-50 \%$, But the virus soon loses its vitality at higher temperatures and relative humidity (such as $38^{\circ} \mathrm{C}$, and relative humidity above $95 \%$ ).

Although, research is still being carried out on the thermal tolerance of SARS-CoV-2, (Wang, Tang, Feng, \& Lv, 2020) concluded that a temperature increase of $1{ }^{\circ} \mathrm{C}$ and a rise in relative humidity by one degree would reduce the effective daily reproductive number of SARS-CoV-2 by 0.0225 and 0.0158 , respectively. In the same vein, Sajadi \& et. al. (2020) 
medRxiv preprint doi: https://doi.org/10.1101/2020.04.16.20067355; this version posted April 17, 2020. The copyright holder for this preprint (which was not certified by peer review) is the author/funder, who has granted medRxiv a license to display the preprint in perpetuity. It is made available under a CC-BY-NC-ND 4.0 International license .

concluded that countries that witnessed a significant transmission of COVID-19 are roughly distributed along the 30-50 N' corridor, which are countries with consistently climate patterns with temperatures ranging from $5-11^{\circ} \mathrm{C}$, combined with low specific $(3-6 \mathrm{~g} / \mathrm{kg}$ ) and absolute humidity (4-7 g / kg ).

\subsection{Age categories most affected by COVID-19}

Several reports and studies have shown that elder age categories are more susceptible to COVID-19 ((WHO), 2020-1; Wei \& Lessler, 2020); Ropert Koch Institut, 2020 (WHO), 2020-2; Kassem, 2020).

\section{Material and Methods}

To achieve the study's objectives, thirty-nine countries were chosen and divided into two groups, twenty-four of which were declared the first COVID-19 case in January 2020, namely: the USA, Italy, Spain, China, Germany, France, UK, South Korea, Australia, Sweden, Malaysia, Japan, Russia, Philippines, Thailand, Finland, Singapore, Hong Kong, Taiwan, Vietnam, Sri Lanka, Cambodia, Macau and Nepal. While fifteen countries witnessed COVID-19 pandemic for the first time on February at the same year, which were: Iran, Switzerland, Belgium, Netherlands, Austria, Brazil, Israel, Norway, Ireland, Czech Republic, Denmark, Argentina, Egypt, Iraq and Lebanon.

Afterward, the temperature average in the most affected cities within the study's two groups from the day of declaring the first case to April 5, 2020 were calculated (as shown in tables 3 and 6). Utilizing non-linear least squares method (Hansen, 2000), the relationships between cases of COVID-19 per million as a dependent variable for each of the study's two groups, and the average temperatures in the most affected cities and median age as independent variables were estimated individually.

\section{Description of the study Sample}

4.1 Countries that reported the first case of COVID-19 in January 2020

Table (1) shows the most affected cities by COVID-19 in the twenty-four countries that witnessed the pandemic for the first time in January 2020. It is noteworthy that COVID-19 cases are mostly concentrated in the central and northern areas in these countries that represent capitals, densely populated cities, economic and financial centers, especially in developed countries. For instance, California, the USA's economic capital, was the most affected in the far northeast. Likewise, the province of Lampodria in 
medRxiv preprint doi: https://doi.org/10.1101/2020.04.16.20067355; this version posted April 17, 2020. The copyright holder for this preprint (which was not certified by peer review) is the author/funder, who has granted medRxiv a license to display the preprint in perpetuity. It is made available under a CC-BY-NC-ND 4.0 International license.

northern Italy, the responsible for $40 \%$ of industrial production ${ }^{2}$ was the most effected Italian area. Furthermore, COVID-19 has swept through Madrid, the Spanish capital, and the most important financial and economic center ${ }^{3}$. As well, the pandemic was concentrated in Wuhan, the transportation and industry hub in central China ${ }^{4}$, and the capital of China's Hubei Province, the source of the SARS-CoV-2 virus. In Germany, the province of Bavaria, the second largest German province in terms of population, the producer of $18 \%$ of the gross German domestic product ${ }^{5}$ was the most affected. As for France, the pandemic targeted Ile-de-France region in north-central France, which is the richest region in Europe, and the most important French and European region in terms of research, development and innovation. In like manner, the pandemic was concentrated in London, the British capital, As well in Diego, the third largest city in South Korea, besides Stockholm, the Swedish capital, and in capitals of the remain countries in this group.

Tables (1) and (2) show that, despite the "January-group" countries experienced the pandemic at close times, however, these countries varied in the total number of COVID-19 cases, which averaged about 38 thousand, with a minimum of nine only in Nepal, and a maximum of about 312 thousand in the USA in the last update of this study's data on April 5, 2020 at 6:49 GMT. Further, the study countries also varied in infection and death rates, and the number of virus detection tests per million citizens. Tables (2) and (3) show that the "January-group" countries differed in average weather temperatures during the pandemic days until the fifth of April 2020. The average temperatures in these countries reached about $14.68^{\circ} \mathrm{C}$ with a minimum of -1.83 in Finland, and a maximum of 30.50 in Thailand.

\footnotetext{
${ }^{2}$ BBC News (2020), Coronavirus: Italian economy takes a body blow, available at: https://www.bbc.com/news/business-51650974, (Accessed: 3 April 2002)

${ }^{3}$ European Commission, Internal Market, Industry, Entrepreneurship and SMEs, Available at: https://ec.europa.eu/growth/tools-databases/regional-innovation-monitor/base-profile/madrid, (Last accessed: 8 April, 2020)

${ }^{4}$ South China Morning Post (2020), Why Wuhan is so important to China's economy and the potential impact of coronavirus, Available at: https://www.scmp.com/economy/chinaeconomy/article/3047426/explained-why-wuhan-so-important-chinas-economy-and-potential, (Accessed: 7 April, 2020)

5 European Commission, Internal Market, Industry, Entrepreneurship and SMEs, Available at: https://ec.europa.eu/growth/tools-databases/regional-innovation-monitor/base-profile/bavaria, (Last accessed: 7 April, 2020)
} 
medRxiv preprint doi: https://doi.org/10.1101/2020.04.16.20067355; this version posted April 17, 2020. The copyright holder for this preprint (which was not certified by peer review) is the author/funder, who has granted medRxiv a license to display the preprint in perpetuity.

It is made available under a CC-BY-NC-ND 4.0 International license .

Table 1: Total cases and most effected cities in 24 countries that first experienced COVID-19 in January 2020

\begin{tabular}{|c|c|c|c|c|c|}
\hline Countries & 1st case & $\begin{array}{l}\text { Days } \\
\text { till } 5^{\text {th }} \\
\text { of April }\end{array}$ & $\begin{array}{l}\text { Total } \\
\text { cases }\end{array}$ & $\begin{array}{c}\text { Cases } \\
\text { per } \\
1 \mathrm{M} \\
\end{array}$ & Most effected cites \\
\hline USA & $20 / 01 / 2020$ & 76 & 311,637 & 941 & New York \\
\hline Spain & $30 / 01 / 2020$ & 66 & 126,168 & 2699 & Madrid \\
\hline Italy & $29 / 01 / 2020$ & 67 & 124,632 & 2061 & Lombardy \\
\hline Germany & $26 / 01 / 2020$ & 70 & 96,092 & 1147 & Munich, Bavaria \\
\hline France & $23 / 01 / 2020$ & 73 & 89,953 & 1378 & Il de France; Paris \\
\hline China & $10 / 01 / 2020$ & 86 & 81,669 & 57 & Wuhan (Hubei) \\
\hline UK & $30 / 01 / 2020$ & 66 & 41,903 & 617 & London \\
\hline S. Korea & $19 / 01 / 2020$ & 77 & 10,237 & 200 & Daegu Metropolitan City \\
\hline Sweden & $30 / 01 / 2020$ & 66 & 6,443 & 638 & Stockholm \\
\hline Australia & $24 / 01 / 2020$ & 72 & 5,635 & 221 & New south wales; Sydney \\
\hline Russia & $30 / 01 / 2020$ & 66 & 4,731 & 32 & Mosco \\
\hline Malaysia & $24 / 01 / 2020$ & 72 & 3,483 & 108 & Selangor, Shah Alam \\
\hline Japan & $14 / 01 / 2020$ & 82 & 3,139 & 25 & Kanto; Tokyo \\
\hline Philippines & $29 / 01 / 2020$ & 67 & 3,094 & 28 & Manila \\
\hline Thailand & $12 / 01 / 2020$ & 84 & 2,169 & 31 & Bangkok \\
\hline Finland & $28 / 01 / 2020$ & 68 & 1,927 & 348 & Uusimaa \\
\hline Singapore & $22 / 01 / 2020$ & 74 & 1,189 & 203 & Singapore \\
\hline Hong-Kong & $22 / 01 / 2020$ & 74 & 862 & 115 & Hong Kong capital city-state \\
\hline Taiwan & $20 / 01 / 2020$ & 76 & 363 & 15 & Taipei \\
\hline Vietnam & $22 / 01 / 2020$ & 74 & 240 & 2 & Hanoi \\
\hline Sri Lanka & $26 / 01 / 2020$ & 70 & 166 & 8 & Sri Jayawardenepura Kotte \\
\hline Cambodia & $26 / 01 / 2020$ & 70 & 114 & 7 & Phnom Penh \\
\hline Macao & $21 / 01 / 2020$ & 75 & 44 & 68 & Municipality of Macau \\
\hline Nepal & $23 / 01 / 2020$ & 73 & 9 & 0.3 & Kathmandu \\
\hline
\end{tabular}

Sources: https://www.worldometers.info/ (Last accessed; $5^{\text {th }}$ April, 2020, 06:49 GMT).

Table 2: COVID-19 spread indicators, Weather temperatures and median age in 24 countries that first experienced COVID-19 in January 2020

\begin{tabular}{|c|c|c|c|c|c|c|c|c|}
\hline & $\begin{array}{c}\text { days till } \\
\mathbf{5}^{\text {th }} \\
\text { April, }_{\mathbf{2 0 2 0}^{(\mathbf{1})}}\end{array}$ & $\begin{array}{c}\text { Total } \\
\text { cases }^{(\mathbf{1})}\end{array}$ & $\begin{array}{c}\text { Death } \\
\mathbf{S ~ p e r} \\
\mathbf{1 M}^{\mathbf{( 1 )}}\end{array}$ & $\begin{array}{c}\text { Cases } \\
\text { per 1M } \\
(\mathbf{1})\end{array}$ & $\begin{array}{c}\text { Weather } \\
\text { temperature } \\
(\mathbf{2})\end{array}$ & $\begin{array}{c}\text { Median } \\
\text { Age }^{(\mathbf{3})}\end{array}$ & $\begin{array}{c}\text { Population } \\
\text { (M) }\end{array}$ & $\begin{array}{c}\text { Tests } \\
\text { per } \\
\mathbf{1 M}^{(\mathbf{1})}\end{array}$ \\
\hline Average & 72.67 & 38162.46 & 37.21 & 456.22 & 14.68 & 37.33 & 120.4929 & 4666 \\
\hline Minimum & 66.00 & 9 & 0 & 0.30 & -1.83 & 23.40 & 0.647194 & 52 \\
\hline Maximum & 86.00 & 311637 & 256 & 2699.00 & 30.50 & 46.90 & 1432.789 & 12005 \\
\hline
\end{tabular}

\section{Sources:}

1) https://www.worldometers.info/ (Last accessed; $5^{\text {th }}$ April, 2020, 06:49 GMT).

2) https://www.accuweather.com

3) http://world.bymap.org/MedianAge.html, 2016 estimation, (last accessed $5^{\text {th }}$ April, 2020). 
medRxiv preprint doi: https://doi.org/10.1101/2020.04.16.20067355; this version posted April 17, 2020. The copyright holder for this preprint (which was not certified by peer review) is the author/funder, who has granted medRxiv a license to display the preprint in perpetuity.

It is made available under a CC-BY-NC-ND 4.0 International license .

Table 3: Average temperature and median age in 24 countries that first experienced COVID-19 in January 2020

\begin{tabular}{|c|c|c|c|c|c|c|c|c|}
\hline \multirow{3}{*}{ Most effected cites } & \multicolumn{7}{|c|}{ Temperature at $^{(1)}$} & \multirow{3}{*}{$\begin{array}{l}\text { Median } \\
\text { Age }^{(4)}\end{array}$} \\
\hline & \multicolumn{2}{|c|}{ First case-day } & \multicolumn{2}{|c|}{ February $^{(2)}$} & \multicolumn{2}{|c|}{ April 5, 2020 } & \multirow{2}{*}{$\begin{array}{l}\text { Monthly } \\
\text { average } \\
\text { temp. }^{\left({ }^{3}\right.}\end{array}$} & \\
\hline & High & Low & High & Low & High & Low & & \\
\hline New York, USA & -1 & -7 & 2 & -3 & 11 & 5 & 1.8 & 37.9 \\
\hline Madrid, Spain & 11 & 8 & 14 & 8 & 16 & 5 & 10.3 & 42.3 \\
\hline Lombardy, Italy & 8 & -2 & 13 & 0 & 17 & 4 & 6.7 & 45.1 \\
\hline Munich, Bavaria, Germany & 9 & -3 & 13 & 6 & 16 & 0 & 6.8 & 46.8 \\
\hline Il de France; Paris, France & 4 & -1 & 13 & 9 & 9 & 2 & 6.0 & 41.2 \\
\hline Wuhan (Hubei), China & 8 & 0 & 13 & 4 & 13 & 6 & 7.3 & 37.1 \\
\hline London, England & 12 & 5 & 10 & 3 & 8 & 2 & 6.7 & 40.5 \\
\hline Daegu Metropolitan City, S. Korea & 9 & -4 & 8 & -2 & 18 & 4 & 5.5 & 41.2 \\
\hline Stockholm, Sweden & 3 & -2 & 5 & -4 & 2 & -4 & 0.0 & 41.2 \\
\hline New south wales; Sydney, Australia & 32 & 22 & 29 & 19 & 26 & 20 & 24.7 & 36.8 \\
\hline Mosco, Russia & 0 & -1 & 1 & -3 & 2 & -4 & -0.8 & 39.3 \\
\hline Selangor, Shah Alam, Malaysia & 36 & 25 & 35 & 25 & 35 & 26 & 30.3 & 28.2 \\
\hline Kanto; Tokyo, Japan & 14 & 5 & 11 & 5 & 10 & 8 & 8.8 & 46.9 \\
\hline Manila, Philippines & 30 & 24 & 32 & 25 & 34 & 27 & 28.7 & 23.4 \\
\hline Bangkok, Thailand & 34 & 26 & 35 & 25 & 36 & 27 & 30.5 & 37.2 \\
\hline Uusimaa, Finland & 3 & 0 & 0 & -9 & 2 & -7 & -1.8 & 42.4 \\
\hline Singapore, Singapore & 32 & 26 & 31 & 26 & 35 & 27 & 29.5 & 34.3 \\
\hline Hong Kong capital city-state & 19 & 14 & 26 & 17 & 21 & 20 & 19.5 & 44.0 \\
\hline Taipei, Taiwan & 20 & 14 & 20 & 15 & 24 & 19 & 18.7 & 40.2 \\
\hline Hanoi, Vietnam & 24 & 18 & 24 & 17 & 25 & 17 & 20.8 & 30.1 \\
\hline Sri Jayawardenepura Kotte, Sri Lanka & 32 & 24 & 33 & 26 & 34 & 26 & 29.2 & 32.5 \\
\hline Phnom Penh, Cambodia & 34 & 23 & 35 & 23 & 38 & 27 & 30.0 & 24.9 \\
\hline Municipality of Macau, Macao & 22 & 15 & 21 & 14 & 20 & 18 & 18.3 & 38.7 \\
\hline Kathmandu, Nepal & 18 & 2 & 23 & 7 & 29 & 11 & 15.0 & 23.6 \\
\hline
\end{tabular}

\section{Sources:}

1) https://www.accuweather.com/en/es/madrid/308526/weather-forecast/308526

2) At the same first case-day, but in February

3) The mean of the lower and upper temperatures in six observations from the first case-day in January until $5^{\text {th }}$ April, 2020

4) http://world.bymap.org/MedianAge.html, 2016 estimation, (last accessed $5^{\text {th }}$ April, 2020).

On the other hand, it is clear from Table (2) that the median age in the "January-group" countries has reached about 37.33 years, with a minimum of 23.40 years in Philippines, and a maximum of 46.90 years in Japan. 
medRxiv preprint doi: https://doi.org/10.1101/2020.04.16.20067355; this version posted April 17, 2020. The copyright holder for this preprint (which was not certified by peer review) is the author/funder, who has granted medRxiv a license to display the preprint in perpetuity.

It is made available under a CC-BY-NC-ND 4.0 International license .

\subsection{Countries that reported the first case of COVID-19 in January 2020}

It is clear from Table (4) that, unlike the "holy city of Qom" in Iran, the COVID-19 pandemic was mainly concentrated in the capitals of countries that witnessed the pandemic in February 2020.

Table 4: Total cases and most effected cities in 15 countries that first experienced COVID-19 in February 2020
\begin{tabular}{|c|c|c|c|c|c|}
\hline Countries & 1st case & $\begin{array}{c}\text { Days till } \\
\mathbf{5}^{\text {th }} \text { of April }\end{array}$ & $\begin{array}{c}\text { Total } \\
\text { cases }\end{array}$ & $\begin{array}{c}\text { Cases } \\
\text { per } \mathbf{1 M}\end{array}$ & $\begin{array}{c}\text { Most effected } \\
\text { cites }\end{array}$ \\
\hline Iran & $18 / 02 / 2020$ & 47 & 55,743 & 664 & Qom \\
\hline Switzerland & $24 / 02 / 2020$ & 41 & 20,505 & 2,369 & Bern \\
\hline Belgium & $03 / 02 / 2020$ & 62 & 18,431 & 1,590 & Brussel \\
\hline Holland & $26 / 02 / 2020$ & 39 & 16,627 & 970 & Amsterdam \\
\hline Austria & $24 / 02 / 2020$ & 41 & 11,781 & 1,308 & Vienna \\
\hline Brazil & $24 / 02 / 2020$ & 41 & 10,360 & 49 & Brasilia \\
\hline Israel & $20 / 02 / 2020$ & 45 & 8,018 & 926 & Tal Aviv \\
\hline Norway & $25 / 02 / 2020$ & 40 & 5,550 & 1,024 & Oslo \\
\hline Ireland & $28 / 02 / 2020$ & 37 & 4,604 & 932 & Dublin \\
\hline Czech R. & $29 / 02 / 2020$ & 36 & 4,475 & 418 & Prague \\
\hline Denmark & $26 / 02 / 2020$ & 39 & 4,077 & 704 & Copenhagen \\
\hline Argentina & $02 / 02 / 2020$ & 63 & 1,451 & 32 & Buenos Aires \\
\hline Egypt & $13 / 02 / 2020$ & 52 & 1,070 & 10 & Cairo \\
\hline Iraq & $21 / 02 / 2020$ & 44 & 878 & 22 & Baghdad \\
\hline Lebanon & $20 / 02 / 2020$ & 45 & 520 & 76 & Beirut \\
\hline
\end{tabular}

Sources: https://www.worldometers.info/ (Last accessed; $5^{\text {th }}$ April, 2020, 06:49 GMT).

It appears from Tables (4), (5) that despite the participation of all countries in this group at the beginning of the pandemic in February 2020, however, these countries also varied in the number of cases of COVID-19, which averaged about 10.94 thousand cases, with a minimum of only 520 cases in the case of Lebanon, and about 55.74 thousand in Iran as a maximum on the fifth of April 2020 at 6:49 GMT. The countries of this group also varied in infection and death rates, and the number of COVID-19 detection tests per million citizens.

Tables (5) and (6) show that the countries that witnessed the pandemic in February differed in the average weather temperatures during the pandemic days until the fifth of April 2020. The average temperatures in these countries reached about 12.34 degrees Celsius, with a minimum of 3.50 in Norway, and a maximum 24.50 in Argentina. On the other hand, Table (5) shows that the median age in the countries of this group reached 34.96 years, with a minimum of 19.90 years in Iraq, and a maximum of 43.80 years in Austria. 
medRxiv preprint doi: https://doi.org/10.1101/2020.04.16.20067355; this version posted April 17, 2020. The copyright holder for this preprint (which was not certified by peer review) is the author/funder, who has granted medRxiv a license to display the preprint in perpetuity.

It is made available under a CC-BY-NC-ND 4.0 International license.

Table 5: COVID-19 spread indicators, Weather temperatures and median age in 15 countries that first experienced COVID-19 in February 2020

\begin{tabular}{|c|c|c|c|c|c|c|c|c|}
\hline & $\begin{array}{c}\text { days till } \\
\text { 5 }^{\text {th }} \text { April, } \\
\mathbf{2 0 2 0}^{(1)}\end{array}$ & $\begin{array}{c}\text { Total } \\
\text { cases }^{(1)}\end{array}$ & $\begin{array}{l}\text { Deaths } \\
\text { per 1M } \\
\text { (1) }\end{array}$ & $\begin{array}{c}\text { Cases } \\
\text { per 1M } \\
(1)\end{array}$ & $\begin{array}{c}\text { Weather } \\
\text { temperat } \\
\text { ure }^{(2)}\end{array}$ & $\begin{array}{c}\text { Median } \\
\text { Age }^{(3)}\end{array}$ & $\begin{array}{l}\text { Population } \\
\text { (M) }^{(1)}\end{array}$ & $\begin{array}{c}\text { Tests } \\
\text { per } \\
\mathbf{1 M}^{(1)}\end{array}$ \\
\hline Average & 44.80 & 10939.33 & 28.72 & 739.6 & 12.34 & 34.96 & 38.43 & $\begin{array}{c}6409.7 \\
3\end{array}$ \\
\hline Minimum & 36 & 520 & 0.1 & 10 & 3.50 & 19.90 & 4.94 & 188 \\
\hline Maximum & 63 & 55743 & 111 & 2369 & 24.50 & 43.80 & 211.43 & 19528 \\
\hline
\end{tabular}

Sources:

1) https://www.worldometers.info/ (Last accessed; $5^{\text {th }}$ April, 2020, 06:49 GMT).

2) https://www.accuweather.com

3) http://world.bymap.org/MedianAge.html, 2016 estimation, (last accessed $5^{\text {th }}$ April, 2020).

Table 6: Average temperature and median age in 15 countries that first experienced COVID-19 in February 2020

\begin{tabular}{|c|c|c|c|c|c|c|c|c|}
\hline \multirow[b]{3}{*}{ Most effected cites } & \multicolumn{6}{|c|}{ Temperature at ${ }^{(1)}$} & \multirow{3}{*}{$\begin{array}{l}\text { Median Age } e^{(4)} \\
\text { First case-day } \\
\text { High }\end{array}$} & \multirow{3}{*}{$\begin{array}{c}\text { Most effected } \\
\text { cites } \\
\text { February }{ }^{(2)} \\
\text { Low } \\
\end{array}$} \\
\hline & \multicolumn{2}{|c|}{ First case-day } & \multicolumn{2}{|c|}{ February ${ }^{(2)}$} & \multicolumn{2}{|c|}{ April 5, 2020 } & & \\
\hline & High & Low & High & Low & High & Low & & \\
\hline Qom & 16 & 1 & 21 & 11 & 20 & 8 & 12.83 & 29.2 \\
\hline Bern & 9 & 2 & 18 & 2 & 18 & -2 & 7.83 & 42.2 \\
\hline Brussel & 11 & 6 & 8 & 2 & 22 & 5 & 9.00 & 41.1 \\
\hline Amsterdam & 7 & 2 & 11 & 1 & 20 & 5 & 7.67 & 42.5 \\
\hline Vienna & 10 & 4 & 8 & -3 & 17 & -1 & 5.83 & 43.8 \\
\hline Brasilia & 26 & 21 & 25 & 20 & 31 & 22 & 24.17 & 31.6 \\
\hline Tal Aviv & 14 & 8 & 8 & 5 & 28 & 12 & 12.50 & 29.7 \\
\hline Oslo & 1 & -4 & 9 & 2 & 10 & 3 & 3.50 & 39.1 \\
\hline Dublin & 13 & 3 & 9 & 4 & 15 & 6 & 8.33 & 36.4 \\
\hline Prague & 8 & -1 & 8 & -1 & 16 & 5 & 5.83 & 41.7 \\
\hline Copenhagen & 7 & 3 & 8 & 2 & 11 & 5 & 6.00 & 42.0 \\
\hline Buenos Aires & 32 & 22 & 31 & 24 & 24 & 14 & 24.50 & 31.5 \\
\hline Cairo & 24 & 13 & 18 & 13 & 29 & 15 & 18.67 & 23.8 \\
\hline Baghdad & 23 & 7 & 22 & 8 & 30 & 18 & 18.00 & 19.9 \\
\hline Beirut & 17 & 14 & 13 & 9 & 16 & 34 & 17.17 & 29.9 \\
\hline
\end{tabular}

\section{Sources:}

1) https://www.accuweather.com/en/es/madrid/308526/weather-forecast/308526

2) At the same first case-day, but in February

3) The mean of the lower and upper temperatures in six observations from the first case-day in January until $5^{\text {th }}$ April, 2020

4) http://world.bymap.org/MedianAge.html, 2016 estimation, (last accessed $5^{\text {th }}$ April, 2020).

\section{Results}

\subsection{Relationship between COVID-19 cases per million and temperature in "January-group" countries}

The exponential function was suggested as in equation (1) to represent the relationship between the number of COVID-19 cases per million as a proxy of transmission as a dependent variable (y), and the weather temperature as an independent variable (x).

$$
y_{i}=\alpha e^{\beta X i}
$$

Where:

$\mathrm{y}_{\mathrm{i}}$ : Number of cases of COVID-19 in country $\mathrm{i}$. 
medRxiv preprint doi: https://doi.org/10.1101/2020.04.16.20067355; this version posted April 17, 2020. The copyright holder for this preprint (which was not certified by peer review) is the author/funder, who has granted medRxiv a license to display the preprint in perpetuity.

$\alpha, \beta$ : The model parameters

$\mathrm{x}_{\mathrm{i}}$ : Average temperature in the country " $\mathrm{i}$ " since the beginning of the first case in January 2002, and until the fifth of April 2020.

Taking the natural logarithm of both sides of equation (1), the following equivalent equation can be obtained:

$$
\ln y_{i}=\ln \alpha+\beta x_{i}
$$

Where it was possible by converting to equation (2), obtaining a formula for a linear regression model, to which the error component $\varepsilon$ can be added, to become as follows:

$$
y_{i}^{\prime}=\alpha^{\prime}+\beta x_{i}+\varepsilon
$$

By applying the non-linear least square method using the mathematical formula as in equation (3), the relationship parameters between the total number of COVID-19 cases in the "January-group" countries, and weather temperatures were estimated as in table (7).

Table 7: Regression model between COVID-19 cases and weather temperature in countries that first experienced COVID-19 in January 2020

\begin{tabular}{|c|c|}
\hline Parameters & Values \\
\hline No. of observations & 24 \\
\hline Adjusted R Square & 0.0798 \\
\hline F & 1.91 \\
\hline Probability > F & 0.1810 \\
\hline Intercept (Standard Error) & $5.4586(1.6039)$ \\
\hline P-value & 0.181 \\
\hline Temperature (X) (Standard Error) & $-0.12081(0.0874)$ \\
\hline P-value & 0.003 \\
\hline
\end{tabular}

Sources: Tables (1) and (3), Using STATA 13.1.

The results in table (7) showed an inverse relationship between the number of cases of COVID-19 per million and temperatures in this group of countries, despite the lack of statistical significance for this relationship.

\subsection{Relationship between COVID-19 cases per million and median age in "January-group" countries}

Utilizing the same exponential formula previously described in equations $(1,2$, and 3$)$, it was possible to estimate the parameters of the relationship between COVID-19 cases per million and the median age as in Table (8). 
medRxiv preprint doi: https://doi.org/10.1101/2020.04.16.20067355; this version posted April 17, 2020. The copyright holder for this preprint (which was not certified by peer review) is the author/funder, who has granted medRxiv a license to display the preprint in perpetuity.

It is made available under a CC-BY-NC-ND 4.0 International license .

Where the results revealed a positive non-statistically significant relationship between COVID-19 cases per million and median age in "January-group" countries.

Table 8: Regression model between COVID-19 cases and median age in 24 countries that first experienced COVID-19 in January 2020

\begin{tabular}{|c|c|}
\hline Parameters & Values \\
\hline No. of observations & 24 \\
\hline Adjusted R Square & 0.0373 \\
\hline F & 1.89 \\
\hline Probability > F & 0.1828 \\
\hline Intercept (Standard Error) & $-3.56608(5.3578)$ \\
\hline P-value & 0.513 \\
\hline Median age (X) (Standard Error) & $0.19425(0.1412)$ \\
\hline P-value & 0.183 \\
\hline
\end{tabular}

Sources: Tables (1) and (3), Using STATA 13.1.

\subsection{Relationship between COVID-19 cases per million and temperature in "February-group" countries}

As well, employing the same exponential formula previously described in equations (1,2, and 3), the parameters of the relationship between COVID19 cases per million and temperature was estimated as in Table (9). Where the results revealed a reverse statistically significant relationship between COVID-19 cases per million and temperature in "February-group" countries.

Substitution by the model (2) parameters as in table (9):

$$
\ln y_{i}=8.466-0.222 x_{i}
$$

Applying e on both sides:

$$
y_{i}=\left(e^{-0.222}\right)^{x}+e^{8.466}=\operatorname{EXP}(-0.222)^{x}+\operatorname{EXP}(8.466)
$$

Equation (5) can be used for predicting the development of COVID-19 cases numbers in light of temperature as shown in Appendix (1). 
medRxiv preprint doi: https://doi.org/10.1101/2020.04.16.20067355; this version posted April 17, 2020. The copyright holder for this preprint (which was not certified by peer review) is the author/funder, who has granted medRxiv a license to display the preprint in perpetuity.

It is made available under a CC-BY-NC-ND 4.0 International license .

Table 9: Regression model between COVID-19 cases and temperature in 15 countries that first experienced COVID-19 in February 2020

\begin{tabular}{|c|c|}
\hline Parameters & Values \\
\hline No. of observations & 15 \\
\hline Adjusted R Square & 0.6599 \\
\hline F & 18.17 \\
\hline Probability > F & 0.0001 \\
\hline Intercept (Standard Error) & $8.46565(0.5812)$ \\
\hline P-value & 0.000 \\
\hline Median age (X) (Standard Error) & $-0.22152(0.0417)$ \\
\hline P-value & 0.000 \\
\hline
\end{tabular}

Sources: Tables (4) and (6), Using STATA 13.1.

\subsection{Relationship between COVID-19 cases per million and temperature in "February-group" countries}

The same manner, using the same exponential formula previously described in equations (1,2, and 3), the relationship between COVID-19 cases per million and median age was estimated as in Table (10).

Table 10: Regression model between COVID-19 cases and temperature in 15 countries that first experienced COVID-19 in February 2020

\begin{tabular}{|c|c|}
\hline Parameters & Values \\
\hline No. of observations & 15 \\
\hline Adjusted R Square & 0.5969 \\
\hline F & 21.73 \\
\hline Probability > F & 0.0004 \\
\hline Intercept (Standard Error) & $-0.80334(1.4320)$ \\
\hline P-value & 0.584 \\
\hline Median age (X) (Standard Error) & $0.18691(0.0410)$ \\
\hline P-value & 0.000 \\
\hline
\end{tabular}

Sources: Tables (4) and (6), Using STATA 13.1.

Where the results revealed a positive statistically significant relationship between COVID-19 cases per million and median age in "February-group" countries.

Substitution by the model (2) parameters as in table (10):

$$
\ln y_{i}=-0.803+0.187 x_{i}
$$

Applying e on both sides: 
medRxiv preprint doi: https://doi.org/10.1101/2020.04.16.20067355; this version posted April 17, 2020. The copyright holder for this preprint

$$
y_{i}=\left(e^{0.187}\right)^{x}+e^{(-0.803)}=\operatorname{EXP}(0.187)^{x}+\operatorname{EXP}(-0.803) .
$$

Furthermore, Equation (7) can be used for predicting the development of COVID-19 cases numbers in light of median age as shown in Appendix (2).

\section{Discussion}

Although the results of the study show that COVID-19 cases per million have increased in countries that have lower weather temperature, as well in countries have higher median age. However, this relationship is not absolute, but rather is related to the number of days since the first case appeared. Where the lower the time from the pandemic starting day, the higher the impact of temperature and median age on the transmission rates. In other words, temperature and median age affect COVID-19 transmission in its early stages, but when cases per million reach a critical mass after successive exponential increase, these two factors no longer have significant influence on the pandemic transmission.

Besides temperature and median age, there are other important factors that have worsened the situation in countries that were heavily invaded by COVID-19, such as the USA, Spain, and Italy, such as the delay in applying mitigation measures for instance. On the contrary to similar countries in terms of temperature at the earliest time of the pandemic i.e. China and South Korea or even Japan that have the higher median age among all the thirty-nine countries in this study, and managed to flatten the exponential growth curve of the pandemic by distinguished mechanisms of early mitigation measures they have applied and utilization of big data techniques in containing the pandemic from its primarily sources.

Referring to the prediction appendices numbers (1), (2), it turns out from table (11) that the number of COVID-19 cases per million in Iran, Switzerland, Belgium, and Israel were higher than its expected values, whether in terms of temperature or median age. As for Norway and Ireland, the registered cases per million were higher than expected in terms of median age, although they were lower than expected as regards to temperature. On the other hand, COVID-19 cases per million in Austria, Czech Republic, Denmark, Egypt and Lebanon were lower than expected in light of both temperature and median age. Almost in like manner, the pandemic cases per million in Netherlands, Brazil, and Argentina were lower than expected pertaining to median age, although these rates were 
medRxiv preprint doi: https://doi.org/10.1101/2020.04.16.20067355; this version posted April 17, 2020. The copyright holder for this preprint (which was not certified by peer review) is the author/funder, who has granted medRxiv a license to display the preprint in perpetuity.

It is made available under a CC-BY-NC-ND 4.0 International license .

slightly higher than expected as far as temperature. As for Iraq, COVID19 cases per million were lower than expected in the light of temperature, although these rates were slightly higher than expected according to the median age.

Table 11: Observed and estimated COVID-19 cases per million* in terms of temperature and median age in the "February-group" countries

\begin{tabular}{|c|c|c|c|c|c|}
\hline \multirow[t]{2}{*}{ Countries } & \multirow[t]{2}{*}{ Temperature } & \multirow[t]{2}{*}{$\begin{array}{c}\text { Median } \\
\text { age }\end{array}$} & \multirow{2}{*}{$\begin{array}{c}\text { Observed } \\
\text { COVID-19 } \\
\text { cases per } \\
\text { 1M }\end{array}$} & \multicolumn{2}{|c|}{$\begin{array}{c}\text { Estimated COVID-19 } \\
\text { cases per } 1 \mathrm{M} \text {, in terms } \\
\text { of }\end{array}$} \\
\hline & & & & Temp. & M. age \\
\hline Iran & 12.83 & 29.2 & 664 & 313 & 102 \\
\hline Switzerland & 7.83 & 42.2 & 2,369 & 941 & 1154 \\
\hline Belgium & 9.00 & 41.1 & 1,590 & 770 & 955 \\
\hline Holland & 7.67 & 42.5 & 970 & 921 & 1163 \\
\hline Austria & 5.83 & 43.8 & 1,308 & 1456 & 1661 \\
\hline Brazil & 24.17 & 31.6 & 49 & 28 & 175 \\
\hline Israel & 12.50 & 29.7 & 926 & 411 & 121 \\
\hline Norway & 3.50 & 39.1 & 1,024 & 2044 & 658 \\
\hline Ireland & 8.33 & 36.4 & 932 & 1001 & 378 \\
\hline Czech R. & 5.83 & 41.7 & 418 & 1456 & 1141 \\
\hline Denmark & 6.00 & 42 & 704 & 1498 & 1149 \\
\hline Argentina & 24.50 & 31.5 & 32 & 29 & 174 \\
\hline Egypt & 18.67 & 23.8 & 10 & 83 & 40 \\
\hline Iraq & 18.00 & 19.9 & 22 & 104 & 19 \\
\hline Lebanon & 17.17 & 29.9 & 76 & 131 & 122 \\
\hline
\end{tabular}

Sources: Author, Tables $(4,6)$ and Tables (1, 2-Annex).

* For April 5, 2020

Observed cases / million is less than estimated

Observed cases / million is slightly higher than estimated

Observed cases / million is higher than estimated

This study's results assume that the data provided by countries to the international organizations are correct and accurate. But in case of assuming that the differences between the observed and expected COVID19 cases in Table (11) are due to underestimation or underreporting, the number of expected total cases per million in some of these countries can be estimated as in table (12).

Generally, the results of this study may raise the question about the extent of the specialty of COVID-19, and its focus on geographical areas in which the major industrial countries concentrate, especially the economic and financial centers. It's highly recommended that the relationship between COVID-19 cases per million and temperature and median age to be estimated at different time periods thereafter, in order to monitor the 
medRxiv preprint doi: https://doi.org/10.1101/2020.04.16.20067355; this version posted April 17, 2020. The copyright holder for this preprint (which was not certified by peer review) is the author/funder, who has granted medRxiv a license to display the preprint in perpetuity.

It is made available under a CC-BY-NC-ND 4.0 International license .

phenomenon at other time periods, either in later stages or more early than that observed in this study.

Table 12: Observed and estimated total COVID-19 cases in some "February-group" countries on April 5, 2020

\begin{tabular}{|c|c|c|c|}
\hline \multirow{2}{*}{ Countries } & $\begin{array}{c}\text { Total COVID-19 } \\
\text { observed cases }\end{array}$ & \multicolumn{2}{|c|}{ Total COVID-19 estimated cases } \\
\cline { 3 - 4 } & 16,627 & Minimum & Maximum \\
\hline Netherlands & 11,781 & NA & 19930 \\
\hline Austria & 5,550 & 13110 & 14964 \\
\hline Norway & 4,604 & NA & 11078 \\
\hline Ireland & 4,475 & 4943 & NA \\
\hline Czech R. & 4,077 & 12213 & 15583 \\
\hline Denmark & 1,451 & 6654 & 8675 \\
\hline Argentina & 1,070 & NA & 7900 \\
\hline Egypt & 878 & 4244 & 8832 \\
\hline Iraq & 520 & 832 & 4151 \\
\hline Lebanon & & & 898 \\
\hline
\end{tabular}

Sources: Author, Tables (4 and 11).

\section{Conclusion}

There are several factors that affect the increasingly transmission of COVID-19, among these factors are the decrease in weather temperature and the increase in the median age of the population. Although, temperature and median age may affect the rates of COVID-19 prevalence in its early stages, but when cases per million reach a critical mass after successive exponential increase, these two factors no longer have significant influence on the pandemic transmission.

\section{References}

(WHO), W. H. (2020-1). Coronavirus disease 2019 (COVID-19): WHO Thailand Situation Report- 23 March 2020. Geneva: WHO.

(WHO), W. H. (2020-2). Report on the WHO-China Joint Mission on Coronavirus Disease 2019 (COVID19). Geneva: WHO.

Altamimi, A., \& Ahmd, E. A. (2019). Climate Factors and Incidence of Middle East Respiratory Syndrome Coronavirus. Journal of Infection and Public Health.

Casanova, L. M., Jeon, S., Rutala, W. A., Weber, D. J., \& Sobsy, M. D. (2010). Effects of Air Temperature and Relative Humidity on Coronavirus Survival on Surfaces. Applied and Environmental Microbiology, 2712-2717.

Chan, H. K., Peiris, J. M., Poon, L. M., \& Seto, H. W. (2011). The Effects of Temperature and Relative Humidity on the Viability of the SARS Coronavirus. Advances in Virology. 
medRxiv preprint doi: https://doi.org/10.1101/2020.04.16.20067355; this version posted April 17, 2020. The copyright holder for this preprint (which was not certified by peer review) is the author/funder, who has granted medRxiv a license to display the preprint in perpetuity.

It is made available under a CC-BY-NC-ND 4.0 International license .

Gundy, P., \& Gebra, C. (2009). Survival of Coronavirus in Water and Wastewater. Food Environ Virol, 1:10(14).

Hansen, B. E. (2000). Econometrics. Wisconsion: University of Wisconsion .

Kassem, A. Z. (2020). "COVID-19" in the World and Egypt: Population Pyramids and Recovery Rates. DOI: 10.13140/RG.2.2.25449.24169/5.

Ropert Koch Institut. (2020). Coronavirus Disease 2019 (COVID-19): Daily Situation Report of the Ropert Kock Institut. Available at: https://www.rki.de.

Sajadi, M., \& et. al. (2020). Temperature, Humidity and latitude analysis to predict potential sread and seasonality for COVID-19. Available at: $h t t p: / / s s r n . c o m / a b s t r a c t=3550308$.

Wang, J., Tang, K., Feng, K., \& Lv, W. (2020). High Temperature and high Humidity Reduce the Transmission of COVID-19.

Wang, J., Tang, K., Feng, K., \& Lv, W. (April 3, 2020). High Temperature and high Humidity Reduce the Transmission of COVID-19.

Wei, L., \& Lessler, J. (2020). Epidemiology and Transmission of COVID-19 in Shenzhen China: Analysis of 391 cases and 1286 of thier contacts. http://researchgate.net/publication/339716563_Epidemiology_ and__Transmission_of _COVID-19_in_Shenzhen_China_Analysis_of_391_cases_and_1286_of_thier_contacts.

\section{Electronic sources:}

(ACCUWEATHER) https://www.accuweather.com

BBC News (2020), Coronavirus: Italian economy takes a body blow, available at: https://www.bbc.com/news/business-51650974, (Accessed: 3 April 2002)

(CITYPOPULATION) https://www.citypopulation.de

European Commission, Internal Market, Industry, Entrepreneurship and SMEs, Available at: https://ec.europa.eu/growth/tools-databases/regional-innovation-monitor/base-profile/ilede-france, (Last accessed: 7 April, 2020)

European Commission, Internal Market, Industry, Entrepreneurship and SMEs, Available at: https://ec.europa.eu/growth/tools-databases/regional-innovation-monitor/base-profile/bavaria, , (Last accessed: 7 April, 2020)

Eurostat, First population estimates: EU population up to over 513 million on 1 January 2019 More death than birth, (Brussels, Eurostat News release, 114/2019, 10 July 2019), available at: https://ec.europa.eu/eurostat/documents/2995521/9967985/3-10072019-BPEN.pdf/e152399b-cb9e-4a42-a155-c5de6dfe25d1

Organization of Economic Cooperation and Development (OCED), Lombardy, Italy, (Paris, OCED, without year), available at: https://www.oecd.org/fr/sites/eduimhe/49008527.pdf

South China Morning Post (2020), Why Wuhan is so important to China's economy and the potential impact of coronavirus, Available at: https://www.scmp.com/economy/chinaeconomy/article/3047426/explained-why-wuhan-so-important-chinas-economy-and-potential, (Accessed: 7 April, 2020)

(WORLDMETERS) https://worldpopulationreview.com (WORLDPOPULATIONREVIEW) https://worldpopulationreview.com/world-cities/madridpopulation/

(WORLD.BYMAP), http://world.bymap.org/MedianAge.html 
medRxiv preprint doi: https://doi.org/10.1101/2020.04.16.20067355; this version posted April 17, 2020. The copyright holder for this preprint (which was not certified by peer review) is the author/funder, who has granted medRxiv a license to display the preprint in perpetuity.

It is made available under a CC-BY-NC-ND 4.0 International license.

\section{Appendices}

Appendix (1): Prediction table of COVID-19 cases per million and temperature after 44.80 days of COVID-19 pandemic*

\begin{tabular}{|c|c|c|c|c|c|}
\hline Temp. $\stackrel{0}{\mathbf{c}}$ & Cases per 1M & Temp. $\stackrel{0}{c}$ & Cases per 1M & Temp. $\stackrel{0}{\mathbf{c}}$ & Cases per $1 \mathrm{M}$ \\
\hline-5 & 17223 & 13 & 317 & 31 & 6 \\
\hline-4 & 13794 & 14 & 254 & 32 & 5 \\
\hline-3 & 11048 & 15 & 203 & 33 & 4 \\
\hline-2 & 8848 & 16 & 163 & 34 & 3 \\
\hline-1 & 7087 & 17 & 130 & 35 & 2 \\
\hline 0 & 5676 & 18 & 104 & 36 & 2 \\
\hline 1 & 4546 & 19 & 84 & 37 & 2 \\
\hline 2 & 3641 & 20 & 67 & 38 & 1 \\
\hline 3 & 2916 & 21 & 54 & 39 & 1 \\
\hline 4 & 2336 & 22 & 43 & 40 & 1 \\
\hline 5 & 1871 & 23 & 34 & 41 & 1 \\
\hline 6 & 1498 & 24 & 28 & 42 & 1 \\
\hline 7 & 1200 & 25 & 22 & 43 & 0.4 \\
\hline 8 & 961 & 26 & 18 & 44 & 0.3 \\
\hline 9 & 770 & 27 & 14 & 45 & 0.3 \\
\hline 10 & 616 & 28 & 11 & 46 & 0.2 \\
\hline 11 & 494 & 29 & 9 & 47 & 0.2 \\
\hline 12 & 395 & 30 & 7 & 48 & 0.1 \\
\hline
\end{tabular}

Sources: Author, Table (6) and equation (5).

* For a community with an average population of 38.43 million and an average age of 34.96 years.

Appendix (2): Prediction table of COVID-19 cases per million and median age after 44.80 days of COVID-19 pandemic

\begin{tabular}{|c|c|c|c|c|c|}
\hline M. age & Cases per 1M & M. age & Cases per 1M & M. age & Cases per 1M \\
\hline 20 & 19 & 31 & 147 & 42 & 1149 \\
\hline 21 & 23 & 32 & 177 & 43 & 1385 \\
\hline 22 & 27 & 33 & 214 & 44 & 1669 \\
\hline 23 & 33 & 34 & 258 & 45 & 2013 \\
\hline 24 & 40 & 35 & 310 & 46 & 2426 \\
\hline 25 & 48 & 36 & 374 & 47 & 2925 \\
\hline 26 & 58 & 37 & 451 & 48 & 3526 \\
\hline 27 & 70 & 38 & 544 & 49 & 4250 \\
\hline 28 & 84 & 39 & 656 & 50 & 5124 \\
\hline 29 & 101 & 40 & 790 & 51 & 6177 \\
\hline 30 & 122 & 41 & 953 & 52 & 7446 \\
\hline
\end{tabular}

Sources: Author, Tables (6) and equation (7).

* For a community with an average population of 38.43 million and an average temperature of $12.34 \stackrel{0}{\mathrm{c}}$. 